This item was submitted to Loughborough's Research Repository by the author.

Items in Figshare are protected by copyright, with all rights reserved, unless otherwise indicated.

\title{
Developing a deeper understanding of the attributes of effective customer contact employees in personal complaint-handling encounters
}

PLEASE CITE THE PUBLISHED VERSION

http://dx.doi.org/10.1108/08876040910985889

PUBLISHER

(C) Emerald Group Publishing Limited

VERSION

AM (Accepted Manuscript)

LICENCE

CC BY-NC-ND 4.0

\section{REPOSITORY RECORD}

Gruber, Thorsten, Isabelle Szmigin, and Roediger Voss. 2019. "Developing a Deeper Understanding of the Attributes of Effective Customer Contact Employees in Personal Complaint-handling Encounters". figshare. https://hdl.handle.net/2134/11921. 
This item was submitted to Loughborough's Institutional Repository (https://dspace.lboro.ac.uk/) by the author and is made available under the following Creative Commons Licence conditions.

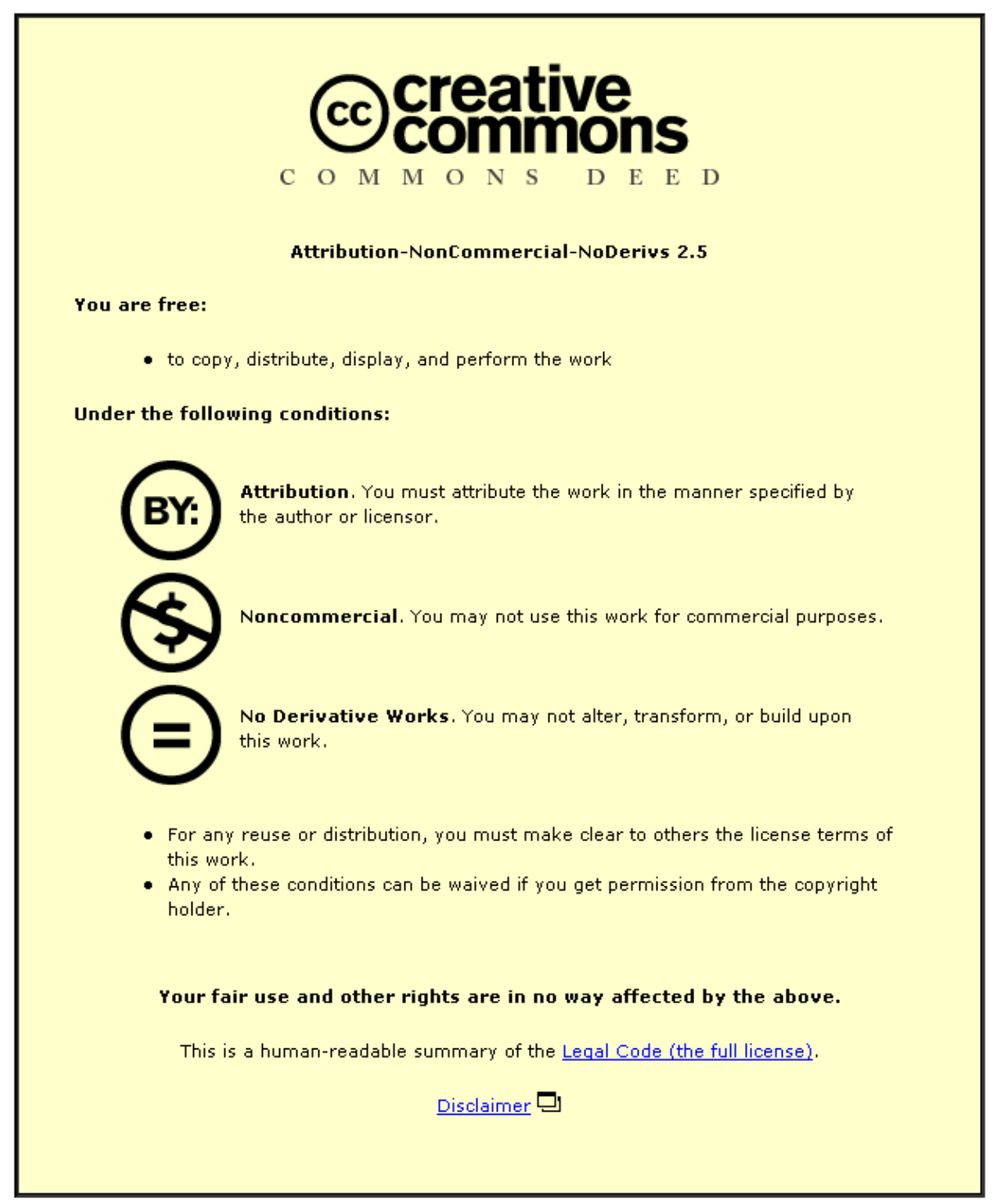

For the full text of this licence, please go to: http://creativecommons.org/licenses/by-nc-nd/2.5/ 


\section{Developing a Deeper Understanding of the Attributes of Effective Customer Contact Employees in Personal Complaint Handling Encounters}

Thorsten Gruber*

The University of Manchester, Manchester Business School, Booth Street West, Manchester M15 6PB, UK, Tel.: +44-(0)161-275 6479 (email: thorsten.gruber@ mbs.ac.uk)

Isabelle Szmigin,

The University of Birmingham, Birmingham Business School, University House, Birmingham B15 2TT, Tel.: +44-(0)121-414 7357 (email: i.t.szmigin@ bham.ac.uk)

Roediger Voss,

Züricher Hochschule für angewandte Wissenschaften, Standort Wädenswill, Abteilung: Facility Management, PF 335, 8820 Wädenswil, CH, Tel.: +41-(0)589345754 (email:

roediger.voss@zhaw.ch)

*Corresponding author 
Purpose - The paper explores the nature of complaint satisfaction. It examines how contact employees should behave and which qualities they should possess. The study also aims to explore the comparability of results obtained from two laddering methods as the alternative techniques may lead to different sets of attributes.

Design/methodology/approach - An exploratory study using the means-end approach and two laddering techniques (personal interviews and questionnaires) was conducted.

Findings - While the personal interviews produced more depth in understanding, the results of the two laddering methods are broadly similar. The research indicates that being taken seriously in the complaint encounter and the employee's listening skills and competence are particularly important.

Research limitations/implications - Due to the exploratory nature of the study and the scope and size of its student sample, the results outlined are tentative in nature.

Practical implications - If companies know what customers expect, contact employees may be trained to adapt their behavior to their customers' underlying expectations, which should have a positive impact on customer satisfaction. For this purpose, the paper gives suggestions to managers to improve active complaint management.

Originality/value - The study was the first to successfully apply the means-end approach and two laddering techniques to the issue of complaint satisfaction. The paper has hopefully opened up an area of research and methodology that could reap considerable further benefits for researchers interested in the area of customer complaint satisfaction.

Keywords - Complaint satisfaction, Means-end approach, Laddering technique Paper type - Research paper 
Developing a Deeper Understanding of the Attributes of Effective Customer Contact Employees in Personal Complaint Handling Encounters

\section{Introduction}

Complaining customers effectively give a company a second chance; if complaints are dealt with effectively the company should be able to recover and even enhance the relationship. Many companies, however, still appear to regard customer complaints as an unpleasant waste of time and money with barriers installed such that some customers believe they have no right to complain. Naylor (2003) estimates that fewer than 50 percent of complainants receive a reply from the company and those that do often view the organization's response as unsatisfactory. Similarly, Andreassen (2001) reports that only 30 percent of complaining customers are happy with the company's complaint handling efforts.

Dissatisfaction with complaint handling is an international phenomenon. Lewis and McCann's (2004) study of service failure and recovery in the UK hotel industry reveals that only just over half of respondents classified themselves as satisfied or very satisfied with the service recovery process. Holloway and Beatty (2003) report that the majority of respondents in their two studies on service failure in online retailing in the US felt injustice following the company's recovery efforts.

In an increasingly service oriented world economy one might be surprised by this apparent disregard of customer complaints, especially when the seriousness of customer dissatisfaction for companies in the short and long term is considered. Disappointed customers may switch to competitors (Homburg and Fürst, 2005) and are likely to engage in negative word-of-mouth (Blodgett et al., 1995). If companies seriously wish to establish successful long-term relationships with their customers they need to avoid the negative consequences of dissatisfaction 
and the high costs of acquiring new customers (Hart et al., 1990). Importantly Dhar and Glazer (2003) point out that repeat purchases by established customers usually require up to $90 \%$ less marketing expenditure than do purchases by first time buyers.

This paper investigates the nature of complaint satisfaction and in particular what qualities and behaviors affect customers during the personal complaint handling encounter. We begin by reviewing the literature on complaint satisfaction and the role of the contact employee in the complaint encounter. We then describe a study that uses the means-end approach and two laddering techniques to develop a deeper understanding of the attributes of effective customer contact employees preferred by complaining customers. Laddering is a semi-standardized qualitative technique that allows researchers to uncover constructs that underlie customers' desire expectations. The paper concludes with a discussion of the nature of the constructs and the implications that these findings have for management and further research in this area.

\section{The nature of complaint satisfaction}

By voicing their concerns, customers show they are still interested in continuing the relationship. The company has an opportunity to solve the problem such that costs (like negative word-of-mouth, switching to other service providers and causing lost turnover), can be prevented or at least minimized (Stauss, 1999). Indeed, research findings reveal that complaint satisfaction can prevent customers from switching to other providers, inhibit negative word-of-mouth communication and even encourage customers to engage in positive communication about the company (Hennig-Thurau, 1999; Stauss, 1999). Handling complaints effectively should turn dissatisfied customers into satisfied ones with the expectation that they will then maintain their relationship with the company (Boshoff and Allen, 2000) and buy from the same supplier again (Stauss 2002). 
Complaint satisfaction can be defined as "the satisfaction of a complainant with a company's response to her/his complaint" (Stauss, 2002, p. 174). Parasuraman et al.'s (1985) expectationsdisconfirmation paradigm provides a useful analogy to understand the subjective evaluation process of complaint satisfaction as customers will compare their expectations concerning the company's complaint handling activities with their perceptions. If the complaint handling experience exceeds expectations, customers should be satisfied, and if it does not they will be dissatisfied; the theory also suggests that they will be indifferent if their perceptions equal their expectations but one might argue that at the very least the relationship may be maintained in such a situation.

\section{The role of customer contact employee behavior}

Although there are many channels available through which to complain, often the complaint is made in person (Brown, 2000). The underlying assumption of this paper is that for such complaints, the qualities and behaviors of customer contact employees have an impact on how customers perceive the encounter and their evaluation of the complaint handling efforts of the company. As skilled and trained customer contact employees are critical players in the recovery from failures (Bell and Luddington, 2006; Boshoff and Allen, 2000; Kau and Loh, 2006; Maxham and Netemeyer, 2003), they should also play an important role for creating complaint satisfaction in face-to-face complaint handling encounters. The services literature supports this proposition; Hartline and Ferrell (1996) for example believe that the behaviors and attitudes of customer contact employees primarily determine the customers' perceptions of service quality. Other studies indicate that the human interaction element is essential to determine whether service delivery will be deemed satisfactory (Chebat and Kollias, 2000). Importantly, employees who are competent, able and willing to solve a problem can increase customers' service encounter 
satisfaction (Bitner et al., 1990). Bitner et al. (1994) recognize that services satisfaction is often affected by the nature of the interpersonal interaction between the customer and the contact employee. Similarly, Van Dolen et al. (2004) and Chung-Herrera et al. (2004) argue that for retail companies, frontline employees operate before during and after a purchase as the primary point of contact and are key to providing good service.

Companies, therefore, need to know what complaining customers expect and how customer contact employees can meet or exceed customer expectations to recover and strengthen the endangered relationship with dissatisfied customers. If companies know what customers expect, contact employees may be trained to adapt their behavior to their customers' underlying expectations, which should have a positive impact on customer satisfaction (Botschen et al., 1999).

The issue of customer expectations and in particular which qualities employees should possess (desire expectations) is still a neglected area (Pieters et al., 1998; Yim, et al., 2003). This paper redresses this gap by examining desire expectations from a complaining customer's point of view. Customers can use such desire expectations as reference standards for satisfaction judgments (Singh and Widing, 1991) and for evaluating recovery performance of service providers (Yim et al., 2003). In addition, desire expectations are more stable and less dependent on the particular service situation than other types of expectations (Zeithaml et al., 1993). Therefore we contend that examining the nature of desire expectations is an important contribution to the area of complaint satisfaction, which is, as we discuss below, underesearched. Despite the publication of a number of studies since Best and Andreasen published their pioneering work in 1977, Kim et al. (2003) still believe that current understanding of complaint satisfaction is limited. They maintain that the literature on consumer complaints has predominantly concentrated on identifying variables that influence complaining behavior such as 
the likelihood of successful redress (Singh, 1990), attribution of blame (Folkes, 1984) or the customer's attitude toward complaining (Richins, 1982). Mc Alister and Erffmeyer (2003) point out that the majority of research work has focused on the characteristics of complaining customers. In a similar vein, authors such as Hocutt et al. (2006), Holloway and Beatty (2003) and McCollough et al. (2000) argue that little is known about how customers evaluate recovery efforts and what the potential limits of recovery to convert dissatisfied customers into satisfied ones are. Winsted (2000) maintains that service providers will only be able to deliver service encounters that will satisfy customers if they understand the critical contact employee behaviors from a customer's point of view.

As outlined above the significance of customer contact employee performance during complaint handling encounters should not be underestimated. Wirtz and Mattila (2004) found that satisfaction is the main variable in service recovery, acting as a mediator variable and explaining the relationship between post-recovery behaviors (negative word-of-mouth communication and repurchase intention) and service recovery dimensions. They suggest that further work is focused on satisfaction as the main dependent variable. From this work and the importance of the contact employee in mediating for complaint satisfaction, this paper will suggest how customer contact employees should behave and what qualities they need to create complaint satisfaction in face-toface encounters.

Given the current lack of knowledge concerning customer desire expectations (Pieters et al., 1998) and the dimensional structure of complaint satisfaction (Stauss, 1999), an exploratory qualitative research study was conducted. The study aimed to identify the qualities and behaviors of customer contact employees most important for customers during personal complaint handling encounters. The research sought to develop a deeper understanding of the attributes (qualities and behaviors) of effective customer contact employees that complaining customers desire and to 
uncover the constructs that underlie these desire expectations. The research study used the means-end approach and the semi-standardized qualitative technique of laddering. With laddering researchers may reveal what Gengler et al. (1999, p. 175) refer to as the "reasons behind the reasons". Consumer researchers should be able to discover information and gain insights into the consumers' personal values and basic motivations. Below we explain how the means-end approach is appropriate and useful in this research study.

\section{Means-end chain approach and laddering technique}

Grunert et al. (2001, p. 63) describe the means-end approach as "one of the most promising developments in consumer research since the 1980s". Researchers are able to examine the consumer's individuality in depth while still producing quantifiable results. Early work in this area helped to resolve product-or brand positioning problems and to link the consumer's product knowledge to his/her self-knowledge (Gutman, 1982; Olson and Reynolds, 1983). The meansend framework has also been applied to the domain of consumer behavior (e.g. Bagozzi and Dabholkar, 1994; Pieters et al., 1995; Pieters et al., 1998), sales management (e.g. Botschen et al., 1999; Deeter-Schmelz et al., 2002; Reynolds et al., 2001a), strategic marketing (e.g. Norton and Reynolds, 2001; Reynolds and Rochon, 2001), services marketing (Gruber et al., 2006; Voss et al., 2007), and new product development (Reppel et al., 2006).

In this research we suggest that the ability of a complaining customer to attain his personal goals and values (ends) depends to a certain degree on the qualities and behaviors of customer contact employees (means) during the personal interaction.

The means-end chain approach (Gutman, 1982; Howard, 1977; Olson and Reynolds, 1983; Young and Feigin, 1975) attempts to discover the salient meanings that consumers associate with products, services and behaviors. The focus is on associations in the consumer's mind between 
the attributes of products, services or behaviors (the "means"), the consequences of these attributes for the consumer, and the personal values or beliefs (the "ends"), which are strengthened or satisfied by the consequences. Attributes are the tangible and intangible characteristics of a product or service. Consequences are the reasons why a certain attribute is important to the consumer. They are the psychological or physiological results that consumers think they can achieve by using the product or service (Gutman, 1982). Values are the consumers' universal life goals and the most personal and general consequences individuals are striving for in their lives (Rokeach, 1973). Consequences (mid level of abstraction) are more relevant to the self than attributes (low level of abstraction) and values (high level of abstraction) are more relevant to the self than personal consequences (Olson and Reynolds, 1983). Effectively this describes a movement at increasingly higher levels of abstraction to desired ends, reflecting progress from the product to aspects of consumers' self concepts (Gutman, 1997). The linkages between attributes, consequences and values are the means-end chains, the mental connections that link the different levels of knowledge (Reynolds et al., 1995).

Two different techniques are available to researchers to produce means-end chains (Botschen and Thelen, 1998; Grunert et al., 2001): The laddering interviewing technique takes subjects up a ladder of abstraction and consists of an elicitation and laddering stage (Reynolds and Gutman, 1988). Interviewers can use elicitation techniques such as triadic sorting, direct elicitation or free sorting to derive preference based distinction criteria. Bech-Larsen and Nielsen (1999) compared five techniques and found that complex methods are both time consuming and do not outperform free sorting techniques such as direct questioning and ranking. The derived criteria from the elicitation stage act as the starting point for the laddering probes which should uncover the complete means-end structure. For this, interviewers repeatedly question why an attribute/consequence/value is important to the respondent. The answer to this question serves as 
the starting point for further questioning. The laddering process continues until respondents give either circular answers, are incapable or reluctant to answer further or reach the value level. The aim of this sequence of probing questions is to identify cognitive relationships of personal relevance to the respondent (Gengler and Reynolds, 1995).

Although the majority of published studies use in-depth laddering interviews (Botschen and Thelen, 1998), there has been some use of laddering questionnaires (Walker and Olson, 1991). Here respondents are asked to write down up to four relevant attributes and then specify with up to three reasons why a certain attribute is important to them. Laddering questionnaires prevent interviewer bias (Botschen and Hemetsberger, 1998) with no social pressure being involved and respondents are able to decide when they want to end the laddering process. Botschen et al. (1999) present the major advantage of the paper-and-pencil questionnaire over the traditional indepth interviewing technique as being cost-efficient data collection. It is also easier to manage and takes less time to collect and analyze the data.

\section{The Study}

The aim of the present study was to use both in depth laddering interviews and questionnaires to develop a deeper understanding of the attributes of effective customer contact employees that complaining customers desire. We wished to uncover the constructs behind these expectations, and to reveal the underlying benefits that complainants look for. The study also aimed to explore the comparability of results obtained from both methods as the alternative techniques may lead to different sets of attributes, which would result in the measurement of different 'excerpts' or parts of the complainants' cognitive structures (Grunert et al., 2001).

The study took place at a large European university. Laddering questionnaires and detailed laddering instructions were handed out to 40 students with complaining experience, aged between 
19 and 39 years $(X=24.3)$ enrolled in a business management course. 28 females and 12 males took part took part on a voluntary basis. The following figure presents the laddering questionnaire that we used in our research study:

"take in Figure 1"

Personal laddering interviews were conducted with 40 students with complaining experience aged between 19 and 45 years $(X=24.8)$ enrolled in another business management course. Here 21 females and 19 males took part. Reynolds et al. (2001b) recommend that laddering studies should include at least 20 respondents so that interviewers can get a significant understanding of the main attributes, consequences, and values of products, services or people. Coolen and Hoekstra (2001) suggest that the number of respondents for laddering interviews should not exceed 50-60 as laddering studies should be predominately exploratory in nature with the focus on discovering relationships and hypotheses rather than testing them. Across the two studies all participants were German students with most of them being in the final year of their university course; they could broadly be referred to as 'middle class' and all had experience of complaining.

At the beginning of each interview respondents were asked to talk about one of their complaining experiences. The idea behind this procedure was to show respondents that the interviewer was genuinely interested in their experiences and to accustom them to the complaining context. We then asked all 40 interviewees: Given that a service or product failure has occurred, what qualities should customer contact employees possess and what behaviors should they exhibit to create complaint satisfaction during personal complaint handling encounters? If respondents specified more than five to eight attributes or characteristics, we then asked them to rank the attributes in order of preference and we selected those attributes with the 
highest ratings as suggested by Reynolds and Gutman (1988) and Deeter-Schmelz et al. (2002). This simple technique of direct questioning was sufficient to elicit salient contact employee attributes and characteristics. For the elicitation of attributes, we decided not to ask respondents to think of a specific industrial sector as we were interested in the behavior and qualities of contact employees and Winsted (2000) discovered that the large majority of behaviors of service employees are the same across different service industries. The derived criteria were the starting point for the laddering probes to uncover the complete means-end structure.

Although several research findings indicate that product or service failure severity has an impact on service recovery/complaint handling encounter evaluations (e.g. Levesque and McDougall, 2000; Mattila, 2001; Smith et al., 1999; Webster and Sundaram, 1998), we still decided not to distinguish between varying levels of service or product failure severity. As stated, we were particularly interested in the complaint handling process and Weun et al. (2004, p. 139) found that "the influence of the process of service recovery on post-recovery satisfaction is stable across varying levels of service failure severity". In particular, they discovered that the importance of interpersonal attributes such as friendliness and courtesy "is the same across both major and minor service failures" (Weun et al., 2004, p. 141). Further, McCollough et al. (2000) argue that the severity of a (service) failure is specific to the context and the individual. What one individual considers to be a low-harm failure can be a high-harm failure for another individual. Similarly, Mattila (2001) believes that every individual will perceive the seriousness of a failure differently based on both individual and situational factors.

\section{Data analysis and results}

Sequences of attributes, consequences and values (the ladders) were coded to make comparisons across respondents. Using the decision-support software program LADDERMAP 
(Gengler and Reynolds, 1993) up to ten chunks of meaning per ladder were entered with the categorization of each phrase as an attribute, consequence or value. Then meaningful categories were identified and grouped. The identification of categories was through phrases and key words that respondents mentioned during the interviews and in the questionnaires and from concepts derived from the literature review. Following Gengler and Reynolds (1995), we combined all codes until a manageable number of approximately 50 remained.

Codes for individual means-end chains were aggregated and expressed in an implications matrix which details the associations between the constructs. The implications matrix acts as a bridge between the qualitative and quantitative elements of the technique by showing the number of times one code leads to another (Deeter-Schmelz et al., 2002). A graphical representation of the aggregate chains was presented in a Hierarchical Value Map (HVM). The map consists of nodes, which stand for the most important attributes/consequences/values (conceptual meanings) and lines, which represent the linkages between the concepts.

Two resulting HVMs detailing the hard and soft laddering are described below. They only display associations beyond cutoff level 3, meaning that linkages had to be mentioned by at least 3 respondents to be represented. The higher the chosen cut-off level, the fewere linkages and constructs of meaning will be displayed, which improves the interpretability of the map. However, if the cut-off level is chosen too high, too many constructs will have disappeared to make it worthwhile. The cutoff level of 3 was chosen as the resulting maps keep the balance between data reduction and retention (Gengler et al., 1995) and between detail and interpretability (Christensen and Olson, 2002).

"take in Figure 2" 
The laddering map reveals a complex cognitive structure. Customers mentioned 13 attributes, 8 consequences, and 6 values. The size of the circle stands for the frequency respondents brought up a certain cognitive concept. Thus, the most critical attributes are friendliness, competence, and active listening. Complainants want contact employees to give positive nonverbal signals ("friendliness"), to have sufficient product (service) knowledge and the authority to handle their problems adequately ("competence"), and they want employees to listen to what they are saying and to hear them out ("active listening"). As the width of the line in the HVM reveals, active listening and friendliness are strongly associated with the consequences "take problem seriously" and "complaint handling". If employees listen actively, customers think that the complaint will be handled ("complaint handling") and that the employee takes the complaint seriously ("take problem seriously"). If customers perceive frontline employees to be competent, they also believe that employees will handle and ultimately solve the problem ("problem solution").

The main consequences are "take someone seriously", which is influenced by several attributes in general and by the employee's courtesy in particular, and "problem solution". Customers think that if employees take them seriously, this will lead to a problem solution. They may also develop trust which is linked with both the values "security" and "justice". Customers believe that the problem can be solved ("problem solution") if employees are honest and if they give the impression of being unbiased ("objectivity"). Complainants want contact employees to be motivated and willing to try hard ("motivation") to solve their problems. They think that the problem can be solved ("problem solution") if employees not only handle the complaint because they have to ("complaint handling") but if they also take it seriously ("take problem seriously") because they are motivated ("motivation"). The HVM also reveals that a speedy complaint resolution will help customers save money and time which makes them feel good ("well-being") and which allows them to better use their time to enjoy life and to have fun ("hedonism"). If 
customers feel good, this frees them from doubts ("security"). For customers to be able to feel secure, employees should ensure transparency and be open to customer suggestions ("openness") as this reduces their customers' uncertainty. In addition, complainants feel equitably treated ("justice") if employees apologize for the problem at hand ("excuse"). According to the HVM, customers particularly want to satisfy the following values: "well-being", which was mentioned 23 times, "justice" (23 times), and "security" (17). Interestingly, customers who feel good ("wellbeing") also feel freed from doubt and have certainty ("security"). These complainants then also feel respected and confident ("self esteem").

Similar to the HVM based on the laddering interviews, the questionnaire version of the HVM (Figure 3) displays a relatively complex cognitive structure.

"take in Figure 3"

Customers mentioned 9 attributes, 11 consequences, and 3 values. The most critical attributes are competence, friendliness, and motivation. Complainants want contact employees to give positive nonverbal signals ("friendliness"), to have sufficient product (service) knowledge and the authority to handle their problems adequately ("competence"), and they want employees to be willing to try hard and to spare no effort ("motivation"). As the width of the line in the HVM reveals, active listening and competence are strongly associated with the consequence "complaint handling". If employees listen actively and are competent, customers think that the complaint will be handled ("complaint handling"). The main consequences are "take someone seriously", which is mainly influenced by the employee's courtesy, "problem handling" and "problem solution". Customers believe that being taken seriously will lead to a problem solution and thus to feelings of satisfaction ("satisfaction"). If employees take complainants seriously, customers may 
continue the relationship ("loyalty"). The frontline employee's friendliness can help customers to feel more at ease and give customers the impression of being in good hands so that they feel happy ("well-being"). If contact employees are friendly, customers sense a good climate between the contact employees and themselves ("atmosphere") and they believe employees are treating them well ("good treatment"). Customers also desire sincere employees ("honesty") so that they can develop trust ("trust"), and employees who take sufficient time to handle the complaint ("take time").

The HVM also shows that a speedy complaint resolution will help customers save time which makes them feel satisfied ("satisfaction") and which allows them to devote attention to other issues ("concentrate on other issues"). Complainants often enter the complaint handling encounter in an angry mood and as a result contact employees have difficulty in resolving complaints as customers are not open to rational explanations and arguments. Customers, however, think that they can assist employees in solving the problem if they are relaxed and have calmed down (“calm down"). In these situations, the frontline employee's friendliness can help customers to feel more at ease. Customers particularly want to satisfy the following values: "satisfaction", which was mentioned 17 times, "well-being" (7 times), and "security" (6). For customers to be able to feel secure ("security"), employees should know their subjects and also have authority to deal with the problem at hand ("competence").

\section{Comparison of Hierarchical Value Maps}

A comparison of the two value maps reveals that the HVM based on the interviews displays more attributes and values but fewer consequences. The four consequences that appeared in the questionnaire HVM but not in the interview HVM, namely "good treatment", "atmosphere", "concentrate on other issues", and "loyalty", however, were also mentioned during the interviews 
but do not appear in the corresponding HVM due to the chosen cutoff level. Similarly, the consequence "save money" appears in the interview HVM but not in the questionnaire HVM due to the cut off level.

"take in Table I"

Table I shows that more attributes and consequences were elicited during laddering interviews than in the laddering questionnaires. Although both laddering techniques revealed eight different values, respondents mentioned almost four times more values during the interviews than in the laddering questionnaires. This also explains the small number of values displayed in the questionnaire HVM (3 values) in comparison to the interview HVM (6 values). It seems to be more difficult for respondents to climb the ladder of abstraction and to elicit associations on the highest value of abstraction without the presence of interviewers. In face-to-face interviews, interviewers can employ several questioning techniques (Reynolds and Gutman, 1988) to help respondents reach the value level which cannot be employed in the paper and pencil version of laddering.

Respondents mentioned more attributes during the personal interviews than in the questionnaires. This can be explained by the fact that the questionnaire design only allows respondents to write down four attributes while they are not so limited during personal interviews. The design of the paper and pencil version of laddering also explains why respondents mentioned a large number of consequences. Respondents can give up to three reasons why a certain attribute is important to them and with the lack of elicited values the respondents mentioned a large number of consequences instead as they were not able to completely climb the ladder of abstraction. 
"take in Table II"

Table II shows that a total of 224 ladders were collected from the laddering interviews and the 40 respondents provided between 3 and 11 ladders each, with an average of 5.6 ladders per respondent. The longest ladder consisted of 9 concepts of meaning (attributes, consequences, and values) and the shortest 2 , with an average of 2.9. By comparison, a total of 135 ladders were collected from the laddering questionnaires and the 40 respondents provided between 1 and 5 ladders each, with an average of 3.4 ladders per respondent. The longest ladder consisted of 5 concepts of meaning (attributes, consequences, and values) and the shortest 2 , with an average of 3.1. These results demonstrate that researchers can collect more ladders (in total and per person) and concepts of meaning during personal laddering interviews than with the paper and pencil version of laddering. Interestingly, the ladders collected from the questionnaires are on average slightly longer than the ladders from the in-depth interviews. Although some ladders collected from the interviews comprised up to nine concepts of meanings, several ladders consisted of only two or three elements.

\section{Discussion and managerial implications}

The analysis of the hierarchical value maps show that customers have specific desire expectations: Customer contact employees need to listen actively to what the complaining customer is saying. "Active listening" is an attribute that respondents mentioned frequently, which supports findings from the personal selling and sales management literature which suggest that the contact employee's listening behavior plays an important role for personal interactions (e.g. Clopton, et al., 2001; De Ruyter and Wetzels, 2000; Ramsey and Sohi, 1997). Contact employees who listen actively receive, process, and respond to messages in such a way that 
further communication is encouraged. Such individuals pay attention to both the speaker's verbal and nonverbal cues and they are also capable of providing both verbal and nonverbal feedback by using all their senses (Comer and Drollinger, 1999).

Complaining customers also desire contact employees who are genuinely friendly, courteous, honest, and who give the impression of being motivated and willing to help. These attributes were mentioned frequently by respondents and illustrate the importance of contact employees having a complaint handling orientation, which can be defined as the willingness and inclination of customer contact employees to continuously improve their complaint handling performance, to make efforts for their customers, and to try to meet their needs throughout the customer to customer contact employee relationship. This definition is based on a review of existing constructs that are used in both theory and practice such as customer orientation (e.g. Williams and Attaway, 1996), service orientation (e.g. Hogan et al., 1984), customer service orientation (e.g. Alge et al., 2002), and commitment to service (Peccei and Rosenthal, 1997). Contact employees should genuinely be helpful and friendly as respondents believed they would notice a feigned friendliness. Contact employees with complaint handling responsibilities should perform their task because they are genuinely willing to help customers and to solve their problems. Complaint handling orientation is neither about the actual performance of the customer contact employee nor about the evaluation of his or her performance. It is a precondition of customeroriented behavior and the contact employee's willingness to handle complaints and to help complaining customers should have a positive impact on his or her complaint handling activities. Complaint handling orientation, however, is only a necessary but not sufficient condition for customer-oriented behavior. Contact employees should also possess sufficient skills to handle complaints effectively. 
In this connection, complaining customers desire contact employees who are competent, which means that they should possess sufficient skills to handle complaints effectively. They should have knowledge about the product or service and they should know what needs doing to solve the problem at hand. According to Van Dolen et al. (2004), competence is an attribute of customer contact employees whereby they can influence the outcome of the interaction through their skills. Complaint handling competence is a resource that contact employees bring to the complaint handling encounter and that does not depend on the complaining customer's input during the encounter (Jaccard et al., 1989; Van Dolen et al., 2004). Complaint handling competence consists of social, professional, and methodological competence (Büdenbender and Strutz, 1996). In particular, respondents want employees to have sufficient product or service knowledge and prior experience to interact successfully with them. This reflects the work of Becker and Wellins (1990) who found that customers want employees to have both an understanding of the company's products and services as well as those policies and procedures that relate to customer service.

The analysis also reveals why employees should be friendly and listen actively: complaining customers require that both they and their complaint are treated seriously. Customers also want contact employees to handle the complaint and solve the problem, which is the main reason for customers to get in contact with the company in the first place. Respondents mentioned several values that they regard as relevant and desirable: self-esteem, well-being, justice, satisfaction, and security. Above all, customers want fair treatment ("justice"). They mentioned that they would have spent money on the product/service that did not meet their expectations and that they would also invest time and effort in bringing the problem to the attention of the company. For these costs, complaining customers expect employees to make equivalent investments. Contact employees need therefore to show effort, to solve the problem and to compensate customers for 
all costs incurred. Respondents also believe that employees should treat them in a friendly manner and with courtesy and respect when the customer is being friendly, courteous and respectful to them. Thus, employees should treat their customers as they would like to be treated. This requires organizations to recruit only individuals who are genuinely willing to help and to act on the behalf of their complaining customers. The found importance of justice also supports findings by authors such as Tax et al. (1998) who believe that customers expect company action in general and justice in particular after having voiced their complaints. Companies should therefore pay attention to the role of justice during all stages of the encounter (Voorhees and Brady, 2005). Finally, complaining customers want to feel they are in good hands ("well-being"). They want to feel safe and to develop trust with contact employees and have certainty ("security"). As a consequence, companies should recognize the role of customer emotions and recruit employees who are capable of detecting complaining customers' emotional states and dealing appropriately with them (Schoefer and Ennew, 2005).

\section{Limitations and directions for further research}

The research study has several limitations. First of all, as the study involved only two groups of students from one university, the results cannot be generalized beyond these groups even though a student sample is likely to represent the general buying public (Bodey and Grace, 2006) and even though our respondents had both sufficient working and complaining experience .

Due to the explorative nature of the study and the scope and size of the sample, the results are tentative in nature. Future research studies should use probability samples that represent the broader (complaining) consumer population. The paper's aim was to give a first valuable indepth insight into what matters for complaining customers by revealing several important constructs. Further research studies should improve our knowledge of complaint satisfaction. 
The study investigated the desired qualities and behaviors of customer contact employees during face-to-face complaint handling encounters as the majority of customers make their complaints in person (Brown, 2000). Moreover, by focusing on face-to-face interactions, the study considered the complete spectrum of qualities and behaviors of contact employees, which other complaint channels do not offer. For example, telephone complaint handling encounters do not allow researchers to examine issues such as nonverbal communication. Further research might investigate the desire expectations of dissatisfied customers who decide to complain in writing, over the phone or by email. In this connection, face-to-face complaint handling is only one part of dealing with product and/or service failures and enhancing customer (complaint) satisfaction.

At the beginning of each laddering interview, respondents talked a little about one of their complaining experiences. While the purpose was to show respondents that the researcher was genuinely interested in their experiences and to accustom them to the complaining context, we cannot be sure whether this description of an experienced complaint handling encounter had an impact on the elicited attributes, consequences, and values. Similarly, Grunert et al. (2001) have suggested that further research could investigate how different framing in terms of situations might lead to different results. Thus, further research should address the issue of situational specificity and investigate the impact of different framing on the results of laddering studies.

While it is expected that interviewers will record information in an unbiased manner, there is, however, a possibility of interviewer bias when conducting personal interviews. Consequently, interviewers have to be skilful at using the techniques of prompting and probing as they could otherwise influence respondents to give a hoped-for answer (Leonard, 2003). We have therefore tried to minimise personal leanings and not to push respondents up the ladder of abstraction but to accompany them on their way up the ladder. It was important for us to find a balance between 
helping respondents to climb up the ladder and avoiding influencing their answers. We are, however, aware of the fact that our personal histories, biography, social class, gender, and ethnicity and those of the respondents may have had an impact on our research results.

The analysis of the laddering questionnaires indicates that only a few respondents were able to reach the highest level of abstraction, explaining the lack in codes at the value level. However, in comparable paper-and-pencil laddering studies (Botschen and Hemetsberger, 1998; Botschen et al. 1999; Pieters et al., 1998) respondents were also only able to come up with few values like "feeling good", "harmony with yourself", and "satisfaction". The reason for the lack of elicited values could be that the means-end approach and the laddering technique are based on Kelly's Personal Construct Psychology (1991/1955). As a consequence, these methods are subject to the limitations of the theory (Gengler et al., 1995). All personal construct approaches depend on the ability and willingness of respondents to reveal their individuality, reflect on their knowledge, and verbalize their experiences. Banister et al. (1994), however, point out that many people may find it difficult to verbalize their experiences and to reflect on their behaviors and attitudes. This may explain why only few respondents who filled in the laddering questionnaires mentioned values. Without the guidance of interviewers most respondents were not able climb the ladder of abstraction.

Research could investigate whether customer desire expectations differ greatly from what contact employees believe customers want. In this connection, Bitner et al. (2000) suggest that service providers may not always know their customers' service quality expectations. Similarly, Mattila and Enz (2002) found a large gap between customer and employee perceptions regarding service quality expectations. An interesting area of further research would be to interview both contact employees and their customers. The resulting hierarchical value maps could highlight different views and compare customers' and employees' perception of the complaint process. 
Insights gained could make contact employees and company managers aware of differing perceptions and identify areas for staff training. They could also use value maps to segment complaining customers and to tailor behavioral strategies to different complaining customer groups.

\section{Conclusion}

This paper has described a study using the means-end chain approach and the laddering technique to investigate complaint satisfaction. We began by outlining the seriousness of disregarding customer complaints and the potential impact on relations between customers and organizations. Companies, we suggest, need to know what complaining customers expect and how customer contact employees can meet or exceed customer expectations to strengthen the endangered relationship with their dissatisfied customers and to avoid negative consequences such as customer switching behavior and negative word-of-mouth communication. The laddering interviews have shown that complaining customers are people first and customers second. The fact that interpersonal factors such as friendliness and listening skills are important, indicate that customers want to satisfy their basic needs first and their expectations and consumption or complaint handling needs second (Oliver, 1997; Schneider and Bowen, 1995). Thus, companies should not only focus on dealing with complaints efficiently, but also offer, what Chebat et al. (2005, p. 340) term "psychological compensation" by redressing complaining customers' emotions as well. A comparison of the two laddering techniques showed that although the results of the two methods are broadly similar, the personal laddering interviews produced more depth in understanding and significantly more respondents were able to reach the value level.

Customer complaint satisfaction is a crucial area for managers and academics alike to focus upon and better understand, especially in the context of long term profitability for the company, 
the success of the company's relationships with customers and the management of employees. Importantly, the voicing of concern indicates customers' willingness to maintain the relationship (Hirschman, 1970) and companies should take advantage of this second chance as most dissatisfied customers do not complain and exit the service instead (Bodey and Grace, 2006). Some dissatisfied customers may even warn their friends and family (Lerman, 2006). Thus, companies ultimately need to turnaround their thinking such that they no longer regard customer complaints as annoying but rather as a valuable source of information for them to improve their services or products (McCole, 2004).

This paper has duly focused on this critical subject and by combining two methods new to this context, the paper has hopefully opened up an area of research and methodology that could reap considerable further benefits for researchers interested in the area of customer complaint satisfaction. 


\section{References}

Alge, B. J, Gresham, M. T., Heneman, R. L., Fox, J. and McMasters, R. (2003), “Measuring customer service orientation using a measure of interpersonal skills: a preliminary test in a public service organization", Journal of Business and Psychology, Vol. 16 No. 3, pp. 467476.

Andreassen, T. W. (2001), "From disgust to delight: do customers hold a grudge?", Journal of Service Research, Vol. 4 No. 1, pp. 39-49.

Bagozzi, R. P. and Dabholkar, P. A. (1994), "Consumer recycling goals and their effect on decisions to recycle: a means-end chain analysis", Psychology and Marketing, Vol. 11 No. 4, pp. 313-340.

Banister, P., Burman, E., Parker, I., Taylor, M. and Tindall, C. (1994), Qualitative Methods in Psychology - A Research Guide, Open University Press, Maidenhead.

Bech-Larsen, T. and Nielsen, N. A. (1999), “A comparison of five elicitation techniques for elicitation of attributes of low involvement products", Journal of Economic Psychology, Vol. 20, pp. 315-341.

Becker, W. S. and Wellins, R. S. (1990), "Customer service perceptions and reality", Training and Development Journal, Vol. 44 No. 3, pp. 49-51.

Bell, S. J. and Luddington, J. A. (2006), "Coping with customer complaints", Journal of Service Research, Vol. 8 No. 3, pp. 192-204. 
Best A. and Andreasen, A. R. (1977), "Consumer responses to unsatisfactory purchases: a survey of perceiving defects, voicing complaints and obtaining redress", Law and Society Review Vol 11, Spring, pp. 701-742.

Bitner, M. J., Booms, B. H. and Tetreault, M. S. (1990), “The service encounter: diagnosing favorable and unfavorable incidents", Journal of Marketing, Vol. 54, January, pp. 71-84.

Bitner, M. J., Brown, S. W. and Meuter, M. L. (2000), “Technology infusion in service encounters”, Journal of the Academy of Marketing Science, Vol. 28 No. 1, pp. 138-149.

Bitner M. J., Booms, B. and Mohr L. A. (1994), “Critical service encounters: the employee’s viewpoint", Journal of Marketing, Vol. 58, October, pp. 95-106.

Blodgett, J. G., Wakefield, K. L. and Barnes, J. H. (1995), “The effects of customer service on consumer complaining behavior”, Journal of Services Marketing, Vol. 9 No. 4, pp.31-42.

Bodey, K. and Grace, D. (2006), "Segmenting service "complainers" and "non-complainers" on the basis of consumer characteristics", Journal of Services Marketing, Vol. 20 No. 3, pp. 178-187.

Boshoff, C. and Allen, J. (2000), “The influence of selected antecedents on frontline staff's perceptions of service recovery performance", International Journal of Service Industry Management, Vol. 11 No. 1, pp. 63-90.

Botschen, G. and Hemetsberger, A. (1998), "Diagnosing means-end structures to determine the degree of potential marketing program standardization", Journal of Business Research, Vol. 42 No. 2, pp. 151-159. 
Botschen, G. and Thelen, E. M. (1998), "Hard Versus Soft Laddering: Implications for Appropriate Use", in Balderjahn, I., Mennicken, C. and Vernette, E. (Eds.), New Developments and Approaches in Consumer Behaviour Research, Schäffer-Poeschel Verlag, Stuttgart, pp. 321-339.

Botschen, G., Thelen, E. M. and Pieters, R. (1999), "Using means-end structures for benefit segmentation”, European Journal of Marketing, Vol. 33 No. 1/2, pp. 38-58.

Brown, S. W. (2000), "Practicing best-in-class service recovery", Marketing Management, Vol. 9, Summer, pp. 8-9.

Büdenbender, U. and Strutz, H. (1996), Gabler Lexikon Personal [Gabler Encyclopedia Personnel], Gabler Verlag, Wiesbaden.

Chebat, J.-C. and Kollias, P. (2000), “The impact of empowerment on customer contact employees' roles in service organizations", Journal of Service Research, Vol. 3 No.1, pp. 66-81.

Chebat, J-C, Davidow, M. and Codjovi, I. (2005), "Silent voices. Why some dissatisfied consumers fail to complain”, Journal of Service Research, Vol. 7 No. 4, pp. 328-342.

Christensen, G. L. and Olson, J. C. (2002), "Mapping consumers' mental models with ZMET", Psychology and Marketing, Vol. 19 No. 6, pp. 477-502.

Chung-Herrera, B. G., Goldschmidt, N. and Hoffman, D. K. (2004), "Customer and employee views of critical service incidents", Journal of Services Marketing, Vol. 18 No. 4, pp. 241-254. 
Clopton, S. W., Stoddard, J. E. and Clay, J. W. (2001), "Salesperson characteristics affecting consumer complaint responses", Journal of Consumer Behaviour, Vol.1 No. 2, pp. 124139.

Comer, L. B. and Drollinger, T. (1999), “Active empathetic listening and selling success: a conceptual framework", Journal of Personal Selling \& Sales Management, Vol. 19 No. 1, pp. $15-29$.

Coolen H. and Hoekstra J. (2001), "Values as determinants of preferences for housing attributes", Journal of Housing and the Built Environment, Vol. 16, September, pp. 285-306.

De Ruyter, K. and Wetzels, M. (2000), “The impact of perceived listening behavior in voice-tovoice service encounters", Journal of Service Research, Vol. 2 No. 3, pp. 276-284.

Deeter-Schmelz, D. R., Kennedy, K. N. and Goebel, D. J. (2002), “Understanding sales manager effectiveness - linking attributes to sales force values", Industrial Marketing Management, Vol. 31 No. 7, pp. 617-626.

Dhar, R. and Glazer, R. (2003), “Hedging Customers”, Harvard Business Review, Vol. 81, May, pp. 86-92.

Folkes, V. S. (1984), “Consumer reactions to product failure: an attributional approach”, Journal of Consumer Research, Vol. 10, March, pp. 398-409.

Gengler, C. E. and Reynolds, T. J. (1993), “LADDERMAP: a software tool for analyzing laddering data, Version 5.4" [Computer software]. 
Gengler, C. E. and Reynolds, T. J. (1995), “Consumer understanding and advertising strategy: analysis and strategic translation of laddering data", Journal of Advertising Research, Vol. 35, July/August, pp. 19-33.

Gengler, C. E., Klenosky, D. B. and Mulvey, M. S. (1995), "Improving the graphic representation of means-end results", International Journal of Research in Marketing, Vol. 12 No. 3, pp. 245-256.

Gengler, C. E, Mulvey, M. S. and Oglethorpe, J. E. (1999), “A means-end analysis of mothers' infant feeding choices", Journal of Public Policy \& Marketing, Vol. 18 No. 2, pp. 172188.

Gruber, T., Szmigin, I. and Voss, R. (2006), “The desired qualities of customer contact employees in complaint handling encounters", Journal of Marketing Management, Vol. 22 No. 5-6, pp. 619-642.

Grunert, K.G., Beckmann, S. C. and Sørensen, E. (2001), “Means-end chains and laddering: an inventory of problems and an agenda for research", in Reynolds, T. J. and Olson, J. C. (Eds.), Understanding Consumer Decision Making - The Means-End Approach to Marketing and Advertising Strategy, Lawrence Erlbaum Associates, Mahwah, NJ, pp. 6390.

Gutman, J. (1982), “A means-end chain model based on consumer categorization processes”, Journal of Marketing, Vol. 46, Spring, pp. 60-72.

Gutman, J. (1997), "Means-end chains as goal hierarchies”, Psychology \& Marketing, Vol. 14 No. 6, pp. 545-560. 
Hart, C. W. L, Heskett, J. L. and Sasser Jr., W. Earl (1990), “The profitable art of service recovery", Harvard Business Review, Vol. 68, July-August, pp.148-156.

Hartline, M. D. and Ferrell, O. C. (1996), "The management of customer-contact service employees: an empirical investigation", Journal of Marketing, Vol. 60, October, pp. 5270.

Hennig-Thurau, T. (1999), "Beschwerdezufriedenheit: Empirische Analyse der Wirkungen und Determinanten einer Schlüsselgröße des Beziehungsmarketing“[Analyzing the determinants and consequences of complaint satisfaction], Jahrbuch der Absatz- und Verbrauchsforschung, Vol. 45 No. 2, pp. 214-240.

Hirschman, A. O. (1970), Exit, Voice and Loyalty, Harvard Press Cambridge, MA.

Hocutt, M. A., Bowers, M. R. and Donavan, D. T. (2006), “The art of service recovery: fact or fiction?", Journal of Services Marketing, Vol. 20 No. 3, pp. 199-207.

Hogan J., Hogan, R. and Busch, C. M. (1984), "How to measure service orientation", Journal of Applied Psychology, Vol. 69 No.1, pp. 67-173.

Holloway, B. B. and Beatty, S. E. (2003), "Service failure in online retailing - a recovery opportunity”, Journal of Service Research, Vol. 6 No.1, pp. 92-105.

Homburg, C. and Fürst, A. (2005), "How organizational complaint handling drives customer loyalty: an analysis of the mechanistic and the organic approach”, Journal of Marketing, Vol. 69, July, pp. 95-114. 
Howard, J A. (1977), Consumer Behavior: Application and Theory, McGraw-Hill, New York, NY.

Jaccard, J., Brinberg, D. and Dittus, P. J. (1989), “Couple decision making: individual- and dyadic-level analysis", in Brinberg, D. and Jaccard, J. (Eds.), Dyadic Decision Making, Springer, New York, NY, pp. 36-50.

Kau. A. K. and Loh, E. W-Y. (2006), "The effects of service recovery on consumer satisfaction: a comparison between complainants and non-complainants", Journal of Services Marketing, Vol. 20 No.2, pp. 101-111.

Kelly, G. A. (1991/1955), The Psychology of Personal Constructs. 2 Volumes, Routledge, London/New York, NY (Reprint 1991; Original 1955: Norton, New York, NY).

Kim, C., Kim, S., Im, S. and Shin, C. (2003), "The effect of attitude and perception on consumer complaint intentions", Journal of Consumer Marketing, Vol. 20 No. 4, pp. 352-371.

Leonard, M. (2003), “Interviews”, in Miller, R. L. and Brewer, J. D. (Eds.), The A-Z of Social Research - A Dictionary of Key Social Science Research Concepts, Sage, London, pp. $166-171$.

Lerman, D. (2006), “Consumer politeness and complaining behaviour”, Journal of Services Marketing, Vol. 20 No. 2, pp. 92-100.

Levesque, T. J. and McDougall, G. H. G. (2000), "Service problems and recovery strategies: an experiment", Canadian Journal of Administrative Sciences, Vol. 17 No.1, pp. 20-37. 
Lewis, B. R. and McCann, P. (2004), "Service failure and recovery: evidence from the hotel industry”, International Journal of Contemporary Hospitality Management, Vol. 16 No. 1, pp. 6-17.

Mattila, A. S. (2001), “The effectiveness of service recovery in a multi-industry setting," Journal of Services Marketing, Vol. 15 No. 7, pp. 583-596.

Mattila, A. S. and Enz, C. A. (2002), "The role of emotions in service encounters", Journal of Service Research, Vol. 4 No. 4, pp. 268-277.

Maxham III, J. G. and Netemeyer, R. G. (2003), "Firms reap what they sow: the effects of shared values and perceived organizational justice on customers' evaluations of complaint handling", Journal of Marketing, Vol. 67, January, pp. 46-62.

McAlister, D. T. and Erffmeyer, R. C. (2003), “A content analysis of outcomes and responsibilities for consumer complaints to third-party organizations", Journal of Business Research, Vol. 56 No. 4, pp. 341-351.

McCole, P. (2004), “Dealing with complaints in services", International Journal of Contemporary Hospitality Management, Vol. 16 No. 6, pp. 345-354.

McCollough, M. A., Berry, L. L. and Yadav, M. S. (2000), “An empirical investigation of customer satisfaction after service failure and recovery", Journal of Service Research, Vol. 3 No. 2, pp. 121-137.

Naylor, G. (2003), “The complaining customer: a service provider's best friend?”, Journal of Consumer Satisfaction, Dissatisfaction and Complaining Behavior, Vol. 16, pp. 241-248. 
Norton, J. A. and Reynolds, T. J. (2001), “The application of means-end theory in industrial marketing”, in Reynolds, T. J. and Olson, J. C. (Eds.), Understanding Consumer Decision Making - The Means-End Approach to Marketing and Advertising Strategy, Lawrence Erlbaum Associates, Mahwah, NJ, pp. 319-334.

Oliver, R. L. (1997), Satisfaction: A Behavioral Perspective on the Consumer, Mc Graw Hill, New York, NY.

Olson, J. C. and Reynolds, T. J. (1983), “Understanding consumers' cognitive structures: implications for marketing strategy", in Percy, L. and Woodside, A. G. (Eds.), Advertising and Consumer Psychology, Lexington Books, Lexington, MA, pp. 77-90.

Parasuraman A., Zeithaml, V. A. and Berry, L. L. (1985), “A conceptual model of service quality and its implications for future research”, Journal of Marketing, Vol. 49, Fall, pp. 41-50.

Peccei, R. and Rosenthal, P. (1997), "The antecedents of employee commitment to customer service: evidence from a UK service context", International Journal of Human Resource Management, Vol. 8 No. 1, pp. 66-86.

Pieters, R., Baumgartner, H. and Allen, D. (1995), “A means-end chain approach to consumer goal structures", International Journal of Research in Marketing, Vol. 12 No. 3, pp. 227244.

Pieters, R., Botschen, G. and Thelen, E.. M. (1998), "Customer desire expectations about service employees: an analysis of hierarchical relations", Psychology \& Marketing, Vol. 15 No. 8, pp. $755-773$. 
Ramsey, R. P. and Sohi, R. S. (1997), "Listening to your customers: the impact of perceived salesperson listening behavior on relationship outcomes", Journal of the Academy of Marketing Science, Vol. 25 No. 2, pp. 127-137.

Reppel, A., Szmigin, I. and Gruber, T. (2006). "The iPod phenomenon: identifying a market leader's secrets through qualitative marketing research", Journal of Product \& Brand Management, Vol. 15 No. 4, pp. 239-249.

Reynolds, T. J. and Gutman, J. (1988), "Laddering theory, method, analysis, and interpretation", Journal of Advertising Research, Vol. 28, February/March, pp. 11-31.

Reynolds, T. J. and Rochon, J. P. (2001), “Consumer segmentation based on cognitive orientations: the Chemlawn case", in Reynolds, T. J. and Olson, J. C. (Eds.), Understanding Consumer Decision Making - The Means-End Approach to Marketing and Advertising Strategy, Lawrence Erlbaum Associates, Mahwah, NJ, pp. 283-298.

Reynolds, T. J., Gengler, C. E. and Howard, D. J. (1995), “A means-end analysis of brand persuasion through advertising”, International Journal of Research in Marketing, Vol. 12 No. 3, pp. 257-266.

Reynolds, T. J, Rochon, J. P. and Westberg, S. J. (2001a), “A means-end chain approach to motivating the sales force: the Mary Kay strategy", in Reynolds, T. J. and Olson, J. C. (Eds.), Understanding Consumer Decision Making - The Means-End Approach to Marketing and Advertising Strategy, Lawrence Erlbaum Associates, Mahwah, NJ, pp. 269-282. 
Reynolds, T. J., Dethloff, C. and Westberg, S. J. (2001b), “Advances in Laddering”, in Reynolds, T. J. and Olson, J. C. (Eds.), Understanding Consumer Decision Making - The MeansEnd Approach to Marketing and Advertising Strategy, Lawrence Erlbaum Associates, Mahwah, NJ, pp. 91-118.

Richins, M. L. (1982), “An investigation of consumer attitudes toward complaining”, in Mitchell, A. (Ed.), Advances in Consumer Research, Association for Consumer Research, Provo, UT, pp. 502-506.

Rokeach, M. J. (1973), The Nature of Human Values, Free Press, New York, NY.

Schneider, B., Bowen, D. Earl. (1995), Winning the Service Game, Harvard Business School Press, Boston, MA.

Schoefer, K. and Ennew, C. (2005), “The impact of perceived justice on consumers' emotional responses to service complaint experiences", Journal of Services Marketing, Vol. 19 No. $5,261-270$.

Singh, J. (1990), "Voice, exit, and negative word-of-mouth behaviors: an investigation across three service categories", Journal of the Academy of Marketing Science, Vol. 18, Winter, pp. $1-15$.

Singh, J. and Widing II, R. E. (1991), "What occurs once consumers complain? - a theoretical model for understanding satisfaction/dissatisfaction outcomes for complaint responses", European Journal of Marketing, Vol. 25 No. 5, pp. 30-46. 
Smith, A. K., Bolton, R. N. and Wagner, J. (1999), “A model of customer satisfaction with service encounters involving failure and recovery", Journal of Marketing Research, Vol. 36, August, pp. 356-372.

Stauss, B. (1999), "Kundenbindung durch Beschwerdemanagement"“ [Customer retention through complaint management], in Bruhn, M. and Homburg, C. (Eds.), Handbuch Kundenbindungsmanagement 2nd Edition [The Customer Retention Management Handbook], Gabler Verlag, Wiesbaden, pp. 213-238.

Stauss, B. (2002), “The dimensions of complaint satisfaction: process and outcome complaint satisfaction versus cold fact and warm act complaint satisfaction", Managing Service Quality, Vol. 12 No. 3, pp. 173-183.

Tax, S. S., Brown, S. W. and Chandrashekaran, M. (1998), “Customer evaluations of service complaint experiences: implications for relationship marketing”, Journal of Marketing, Vol. 62, April, pp. 60-76.

Van Dolen, W., De Ruyter, K. and Lemmink, J. (2004), “An empirical assessment of the influence of customer emotions and contact employee performance on encounter and relationship satisfaction", Journal of Business Research, Vol. 57 No. 4, pp. 437-444.

Vorhees, C. M. and Brady, M. K. (2005), “A service perspective on the drivers of complaint intentions", Journal of Service Research, Vol. 8 No. 2, pp. 192-204.

Voss, R., Gruber, T. and Szmigin, I. (2007). "Service quality in higher education: the role of student expectations”, Journal of Business Research, Vol. 60 No. 9, 949-959. 
Walker, B. A. and Olson, J. C. (1991), "Means-end chains: connecting products with self", Journal of Business Research, Vol. 22 No. 2, pp. 111-118.

Webster, C. and Sundaram, D. S. (1998), "Service consumption criticality in failure recovery”, Journal of Business Research, Vol. 41, pp. 153-159.

Weun, S., Beatty, S. E. and Jones, M. A. (2004), “The impact of service failure severity on service recovery evaluations and post-recovery relationships", Journal of Services Marketing, Vol. 18 No. 2, pp. 133-146.

Williams M. R. and Attaway, J. S. (1996), “Exploring salespersons’ customer orientation as a mediator of organizational culture's influence on buyer-seller relationships", Journal of Personal Selling \& Sales Management, Vol. 4, Fall, pp. 33-52.

Winsted, K. F. (2000), "Service behaviors that lead to satisfied customers", European Journal of Marketing, Vol. 34 No. 3/4, pp. 399-417.

Wirtz, J. and Mattila, A. S. (2004), “Consumer responses to compensation, speed of recovery and apology after a service failure", International Journal of Service Industry Management, Vol. 15 No. 2, pp. 150-166.

Yim, C. K., Gu, F. F., Chan, K. W. and Tse, D. K. (2003), “Justice-based service recovery expectations: measurement and antecedents", Journal of Consumer Satisfaction, Dissatisfaction and Complaining Behavior, Vol. 16, pp. 36-52.

Young, S. and Feigin, B. (1975), "Using the benefit chain for improved strategy formulation", Journal of Marketing, Vol. 39, July, pp. 72-74. 
Zeithaml, V. A., Berry, L. L. and Parasuraman, A. (1993), "The nature and determinants of customer expectations of services", Journal of the Academy of Marketing Science, Vol. 21 No. 1, pp. 1-12. 
Figure 1. Paper-and-Pencil Version of Laddering (adapted from Pieters et al. (1998, p. 760) and Botschen and Hemetsberger (1998, p. 154))

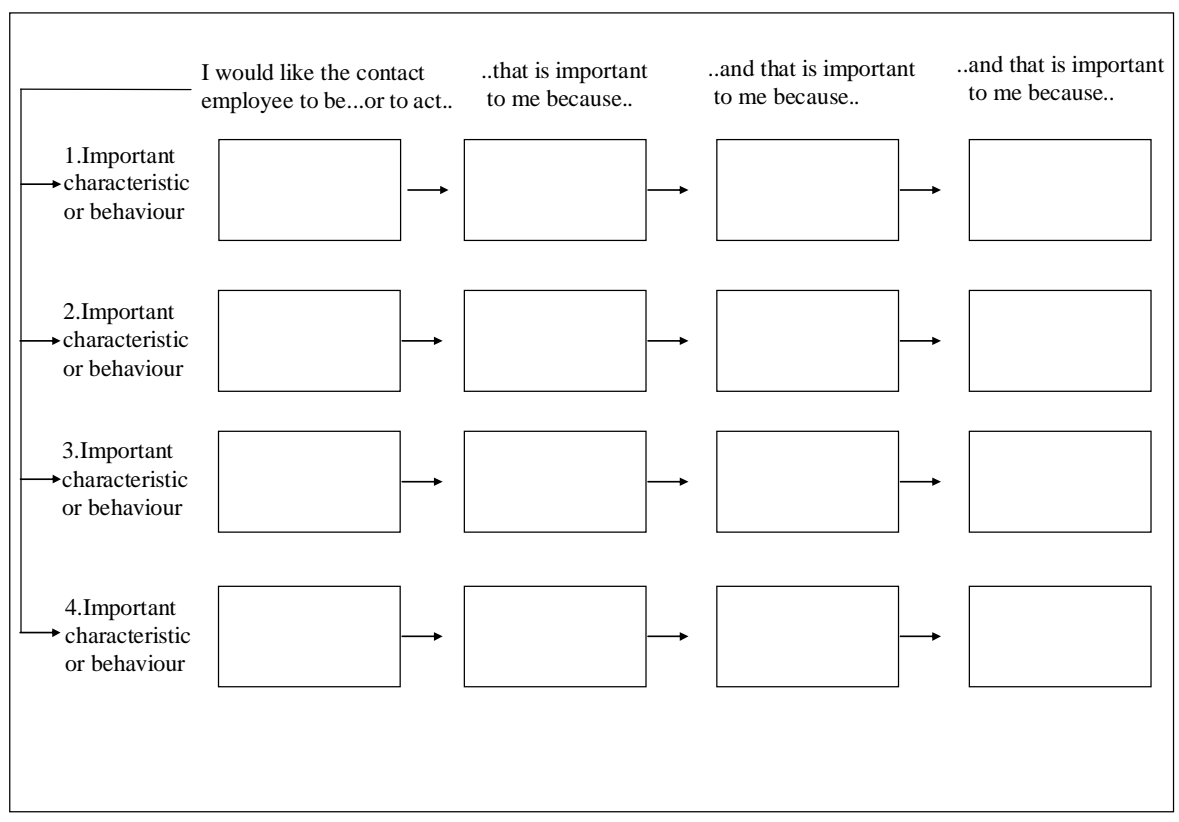


Figure 2. Hierarchical Value Map of all Respondents (Laddering Interviews) (The following two abbreviations were used: TAKE PROB SERIOUSLY = Take problem seriously; PERSON=Personalization; MOTIV=Motivation.

White circles represent attributes, grey circles consequences, and black circles values.

Numbers (N) refer to concepts revealed in the ladders and not to the number of respondents.)

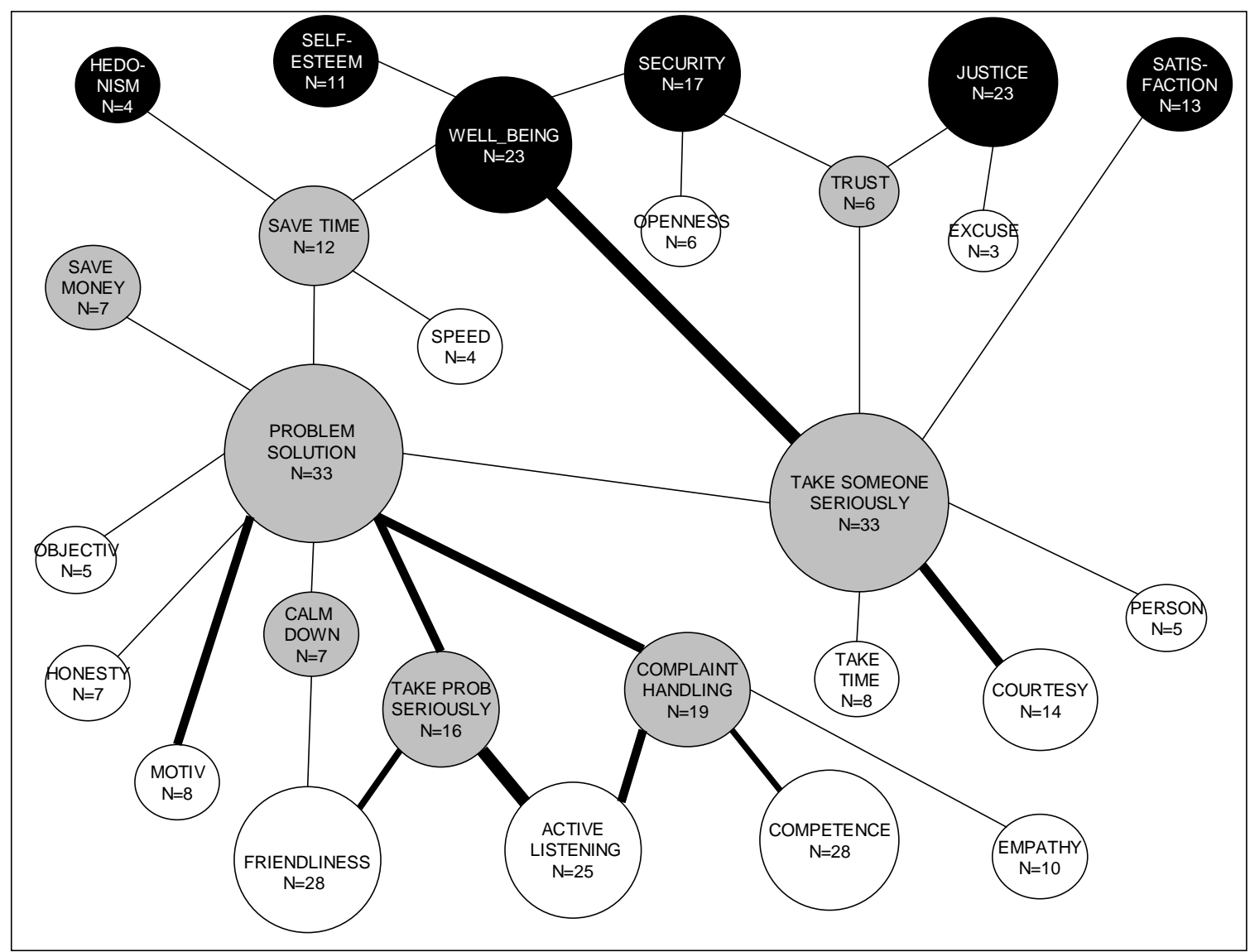


Figure 3. Hierarchical Value Map of all Respondents (Laddering Questionnaires) The following two abbreviations were used: TAKE PROB SERIOUSLY = Take problem seriously; OTHER ISSUES = Concentrate on other issues.

White circles represent attributes, grey circles consequences, and black circles values.

Numbers (N) refer to concepts revealed in the ladders and not to the number of respondents.)

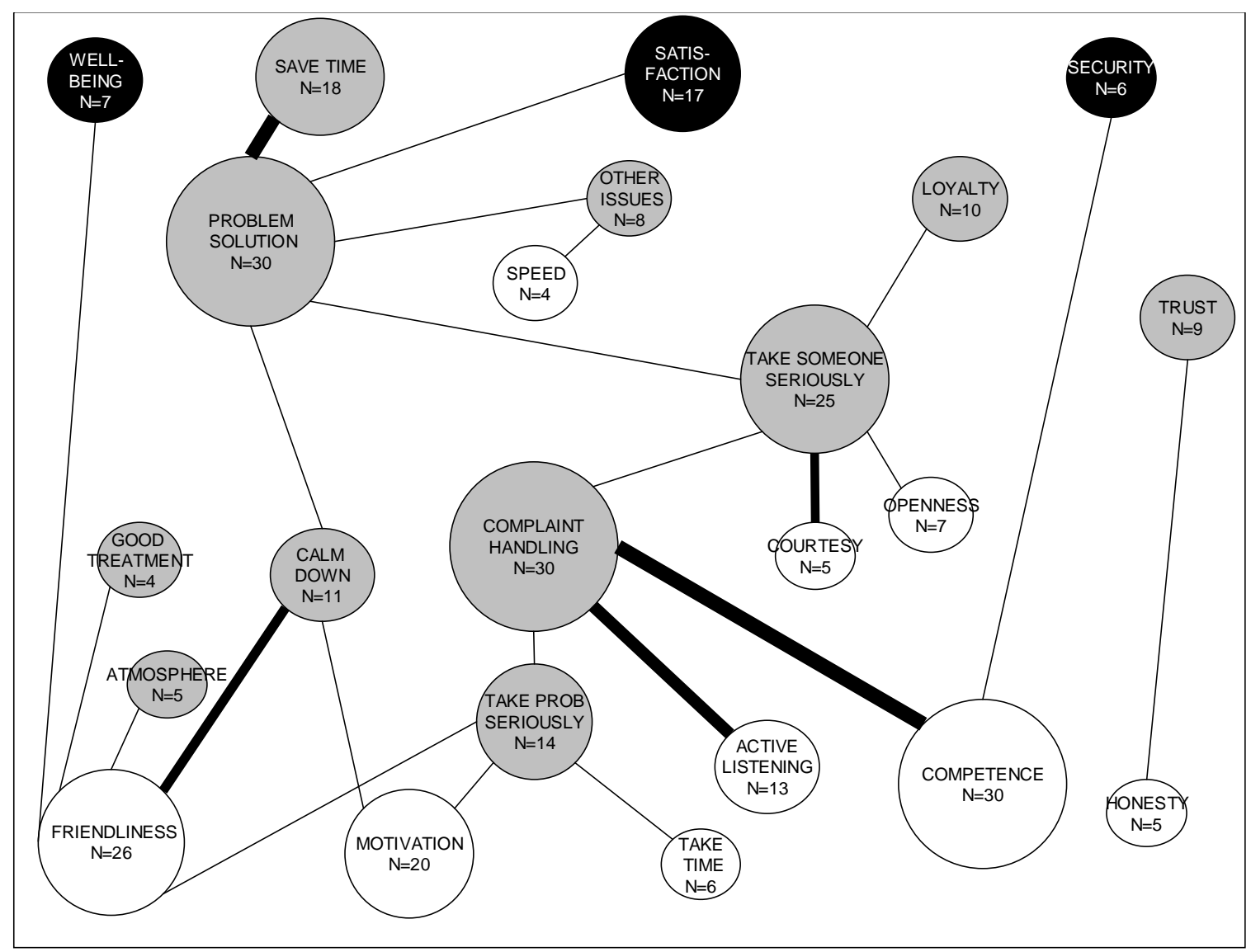


Table I. Comparison of Attributes, Consequences, and Values

\begin{tabular}{|c|c|c|c|c|c|c|c|}
\hline & \multicolumn{2}{|c|}{ Attributes } & \multicolumn{2}{|c|}{ Consequences } & \multicolumn{2}{|c|}{ Values } & \multirow{2}{*}{$\begin{array}{c}\text { Sum of } \\
\text { Concepts } \\
\text { of } \\
\text { Meaning }\end{array}$} \\
\hline & $\begin{array}{c}\text { Number } \\
\text { of } \\
\text { attributes }\end{array}$ & $\begin{array}{c}\text { Number } \\
\text { of times } \\
\text { mentioned } \\
\text { in ladders }\end{array}$ & $\begin{array}{c}\text { Number } \\
\text { of } \\
\text { consequences }\end{array}$ & $\begin{array}{c}\text { Number } \\
\text { of times } \\
\text { mentioned } \\
\text { in ladders }\end{array}$ & $\begin{array}{l}\text { Number } \\
\text { of } \\
\text { Values }\end{array}$ & $\begin{array}{l}\text { Number } \\
\text { of times } \\
\text { mentioned } \\
\text { in ladders }\end{array}$ & \\
\hline $\begin{array}{l}\text { Laddering } \\
\text { Interviews }\end{array}$ & 21 & 219 & 23 & 277 & 8 & 161 & 657 \\
\hline $\begin{array}{l}\text { Laddering } \\
\text { Question- } \\
\text { naires }\end{array}$ & 15 & 138 & 15 & 245 & 8 & 41 & 424 \\
\hline
\end{tabular}


Table II. Comparison of Number and Length of Ladders

\begin{tabular}{|c|c|c|c|c|c|c|c|c|}
\hline & $\begin{array}{l}\text { Number } \\
\text { of } \\
\text { ladders }\end{array}$ & \multicolumn{3}{|c|}{$\begin{array}{l}\text { Number of ladders per } \\
\text { respondent }\end{array}$} & \multirow{2}{*}{$\begin{array}{l}\text { Number } \\
\text { of } \\
\text { concepts } \\
\text { of } \\
\text { meaning } \\
\text { (A/C/V) }\end{array}$} & \multicolumn{3}{|c|}{$\begin{array}{l}\text { Number of concepts of } \\
\text { meaning per ladder } \\
\text { (=Length of ladder) }\end{array}$} \\
\hline & & Min & Max & Average & & Min & Max & Average \\
\hline $\begin{array}{l}\text { Laddering } \\
\text { Interviews }\end{array}$ & 224 & 3 & 11 & 5.6 & 657 & 2 & 9 & 2.9 \\
\hline $\begin{array}{l}\text { Laddering } \\
\text { Questionnaires }\end{array}$ & 135 & 1 & 5 & 3.4 & 424 & 2 & 5 & 3.1 \\
\hline
\end{tabular}

